\title{
自動車保有・利用コストに着目した松山都市圏 におけるカーシェアリングの潜在需要分析
}

\author{
石村 龍則 1 - 倉内 慎也 2 - 萩尾 龍彦3 \\ 1学生会員 愛媛大学大学院理工学研究科生産環境工学専攻（干790-8577 愛媛県松山市文京町3） \\ E-mail: ishimura.tatsunori.06@cee.ehime-u.ac.jp \\ 2正会員 愛媛大学大学院講師 理工学研究科生産環境工学専攻（下790-8577 愛媛県松山市文京町3） \\ E-mail: kurauchi@cee.ehime-u.ac.jp \\ 3 学生会員 愛媛大学大学院理工学研究科生産環境工学専攻（干790-8577 愛媛県松山市文京町3） \\ E-mail: hagio.tatsuhiko.05@cee.ehime-u.ac.jp
}

\begin{abstract}
本研究では, 地方都市である松山市における, カーシェアリング普及に必要な基礎情報を得ることを目 的とし, 潜在需要分析を行った。 具体的には, 自動車保有, 利用にかかるコストと, カーシェアリングに かかるコストを比較し, カーシェアリングによってコストが削減されれば, その自動車を削減可能である と定義し, 削減可能台数の多いエリアの推定を実施した。結果, PT調査を用いた1日当たりの分析では, 松山市の約7割の自動車が削減可能で, 特に都市周辺地区のセカンドカーが削減可能性が高く, PP調查を 用いた1週間当たりでの分析では, 約7割の車両が削減可能であることが判明した.
\end{abstract}

Key Words : car sharing, car ownership and use, person trip survey data, probe person data

\section{1. はじめに}

20 世紀後半の急速なモータリゼーションの進展によ り，交通渋滞などの都市交通問題や大気污染などの都市 環境問題が発生している。このような現状の中で，過度 に自動車に依存した交通のあり方を見直し，個人のモビ リティを尊重しながらも自動車への依存を削減しょうと する取り組みが各地で試みられている. そのような方策 の一つに，カーシェアリング (なお，以下の図表中では カーシェアリングを CS と略記する) がある.

カーシェアリングとは，一台の自動車を複数の人々で 共同利用する会員制のシステムである ${ }^{1)}$. 様々なシステ ム提供パターンがあり, 集合住宅の管理者が駐車場を力 ーシェアリングのデポとして, 居住者に対してカーシェ アリングサービスを提供, また，レンタカー会社が新た にカーシェアリングサービスを開始する場合などがある。 レンタカーとの主な違いは, 貸出時間が 15 分単位であ るため短時間の自動車利用が安い料金で可能であること, 無人であり, 24 時間利用可能であること, ガソリン代 が不要, などが挙げられる. 我が国においても, 大都市 を中心に近年急速に普及している. カーシェアリングは マイカー保有と比心，自動車の購入費や駐車場代等を要
せずに格安で個別のモビリティが利用可能となり ${ }^{1)}$ ，ま た，過剩な自動車利用の抑制や駐車スペースの削減によ る土地利用の効率化などの社会的効果も見込まれる.

カーシェアリングシステムには, 車両の返却方法が 2 種類存在し，3 つの利用パターンに分類できる. まず, 車両の返却方法としては，ラウンドトリップ型とワンウ エイトリップ型があり, ラウンドトリップ型は, 貸し出 した駐車場に車両を返却しなければならないのに対し, ワンウェイトリップ型は, 貸し出した駐車場以外の駐車 場にも返却することが可能であり，利用者にとってはラ ウンドトリップ型に比べて自由度が高い.しかし後者は,

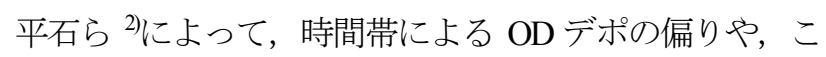
れに伴う行き先駐車場の受け入れ駐車場所確保が問題と されており, 特に余剩駐車場の確保必要性の増大, 駐車 場確保が困難な場合には駐車場間で車両の回送, 再配車 に伴う労働力及びコスト負担の増大が問題であると指摘 されている. 次に, 利用パターンについて述べる. カー シェアリングの利用パターンは, 導入地域の属性及び対 象とするトリップ属性から, シティーカー型, セカンド カー型, ステーション型の 3 種類に分類される. シティ 一カ一型は，主に都心部で業務利用や都心居住者の日常 利用を対象とし，セカンドカー型は郊外住宅地などでの 
買物等の自由目的トリップを対象としたものである.ま た，ステーションカー型は郊外通勤駅で通勤と業務利用 を対象としている. 竹内・谷口 ${ }^{31}$ は, 大阪市内でカーシ エアリングの社会実験を行い, アンケート調査を行った 結果，シティーカー型では短時間で利用可能なシステム が望まれていることを指摘している，平石ら ${ }^{4} は$ は，潜在 需要推定モデルから，ステーション型カーシェアリング の利用意向の傾向は, 20 歳代以下または 50 歳代, 所得 の低い層, 世帯保有台数が複数, 現在自動車で通勤して いても鉄道に乗り換えて通勤する頻度が一定以上といっ た条件を満たす層で利用されやすいことを示し，逆に利 用意向が下がる要因としては，鉄道へ転換時の通勤時間 が長くなりすぎる場合, 鉄道で通勤するときのアクセ ス・イグレス手段として路線バスまたは企業バスがある 場合などがあることを指摘している.

我が国のカーシェアリング車両台数と会員数の推移を 図-1 に示寸. 図-1 より, 車両台数, 会員数共に年々増 加傾向にあることがわかる. 特に, 2011 年に着目寸る と, 我が国のカーシェアリング車両ステーション数は 2,917 ヶ所（前年の 3.4 倍），車両台数は 3,911 台（同 3.0 倍），会員数は 73,224 人（同 4.5 倍）と前年から急激な 増加が見られる. また, 国外での組織的なカーシェアリ ングは, 1980 年代後半に欧州で始まり，90 年代には北 米などに広まった. 2006 年時点では，欧米を中心に世 界 18 力国, 600 都市で運営されており, 利用者人口は 348,000 人, 車両数は 11,700 台に達している5 .

しかしながら，交通エコロジー・モビリティー財団 ${ }^{5}$ の，「現状は，ようやくカーシェアリングという言葉が しられたものの，まだその使い方，効用といったものは， レンタカーと同様のレベルまでは理解されていないのが 実情である」との報告があるように，本格実施にあたつ ては多くの課題を抱えている. 中でも事業採算性の問題 はカーシェアリングの普及において重要な問題であり,

都市圈レベルでその需要や効果について分析した事例は 少ない. そのような現状の中, 松實ら は, 中京都市圈 パーソントリップ調査データ（以下 PT 調査）を用いて, 自動車保有・利用費用に着目したカーシェアリングの潜 在需要分析を行っており, カーシェアリングシステム導 入による単位面積当たりの利用者便益は, 駅周辺地区で 大きい事を示している. しかし，PT調査は平日 1 日の データであるため, 自動車利用パターンの日変動を見る ことができず，休日の自動車利用についても考慮されて いない，世帯の自動車利用パターンは，平日と休日で大 きく異なると樋口らかが指摘しており, 休日を含んだ長 期的なデータを用いた分析が必要であると考えられる. 加えて, 東京, 大阪などの大都市では社会実験が行われ, カーシェアリングに関する分析は進んでいるが，地方都 市においては進んでおらず2)，図-2を見てもわかるよう

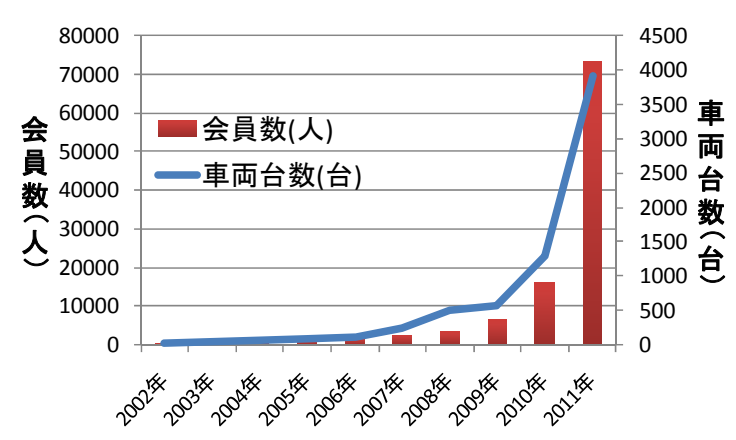

図-1 CS 車両台数と会員数の推移

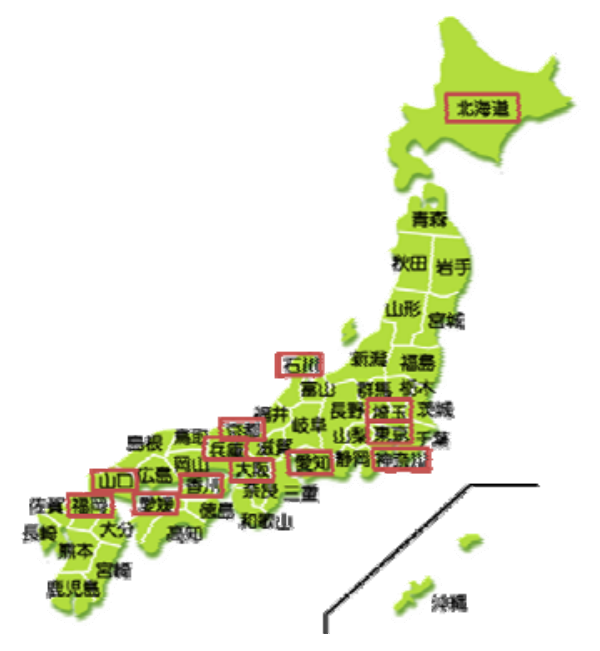

図-2 カーシェアリング実施地

に，カーシェアリングが導入されているのは東京，大阪， 京都など大都市を中心としたエリアとなっており，地方 都市ではあまり導入されていない5)。自動車依存度の高 い地方都市においても，カーシェアリング導入を検討寸 る意義はあろう。

そこで本研究は, 地方都市である松山市における, カーシェアリング普及に必要な基礎情報を得ることを目 的とし，まず松山都市圈 PT 調査データを用いて，世帯 の自動車保有・利用状況を把握し，カーシェアリングへ の転換による利用者の物理的コスト削減効果に着目して 分析を行う。具体的には, 自動車保有, 利用にかかる物 理的コストと, カーシェアリングにかかる物理的コスト を比較する. カーシェアリングによって物理的コストが 削減されれば, 保有者は自動車を手放し, カーシェアリ ングへ移行する可能性があるとして，カーシェアリング への潜在需要があると定義する. 手放す可能性がある自 動車の台数，すなわち削減可能台数が多いエリアを空間 的に見ることで，カーシェアリングへの潜在需要が高い エリアの推定を実施した. 次に, 休日を含む長期的なデ ータである，松山都市圈プローブパーソン調査（以下 PP 調查）を用いて，1週間における自動車の利用状況， カーシェアリングへの転換による利用者の物理的コスト 削減効果に着目して上記と同様の分析を行う。これらの 
表-1 松山都市圏 PT 調査の概要

\begin{tabular}{|c|c|}
\hline 対象地域 & $\begin{array}{l}\text { 松山市, 東温市, 松前町の全域 } \\
\text { 碈部町およ゙伊予の一部地域 }\end{array}$ \\
\hline 配布日時 & 2007 年 10 月 12月 \\
\hline 対象者 & 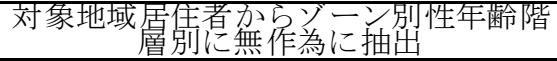 \\
\hline $\begin{array}{c}\text { 回収サンプ } \\
\text { ル数 }\end{array}$ & 12,823 世帯 \\
\hline 調査項目 & 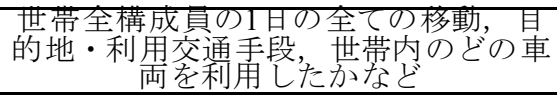 \\
\hline
\end{tabular}

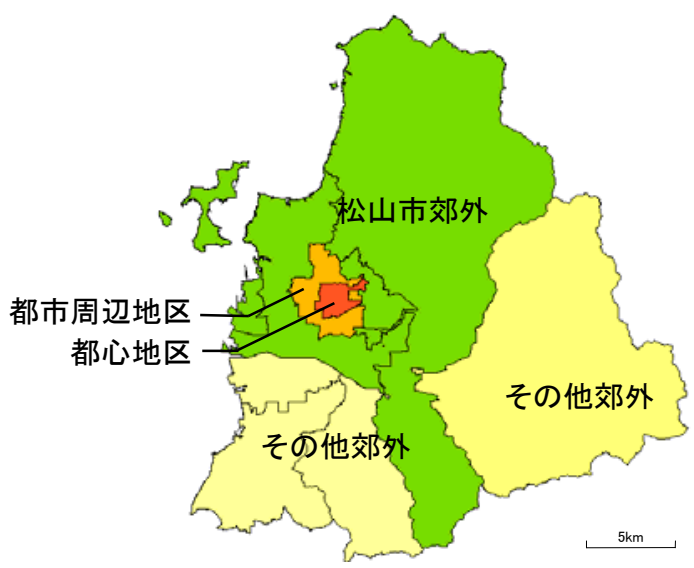

図-3 松山都市圏 PT 調査の対象地域と地区分類

分析結果から，自動車を手放し，カーシェアリングに転 換する可能性を検討する.

\section{2. データ概要}

\section{（1）松山都市圏 PT 調査}

松山都市圏 PT 調査の調査概要を表-1 に，対象地域を 図-3に示す.

ここで，PT 調査に含まれるサンプルは，ゾーンおよ び性年齢階層別の層別任意抽出によって得られたデータ であるため，ゾーン別性年齢階層の分布に応じて拡大係 数が付与されている. 従って，同一世帯内でも個人ごと に拡大係数が異なり，また，自動車保有台数は世帯単位 で回答を得ているため，都市圏レベルでのカーシェアリ ングの潜在市場規模を把握する上では不都合が生ずる. そこで，本研究では，世帯属性と個人属性の双方の母集 団分布に適合させることを目的として開発された IPU (Iterative Proportional Updating) 法 ${ }^{8)}$ を用いて拡大係数を 算出した. なお，自動車保有台数については自治体レべ ルで集計されているため，以降の分析では図-3の「そ の他郊外」地区を除いた松山市のデータのみを用いた.

\section{（2）松山都市圏 PP 調査}

松山都市圈 PP 調査の調査概要を表-2 に示す．特徵と して，日頃自動車を利用されている方を対象としている 表-2＼cjkstart松山都市圈 PP 調査の概要

\begin{tabular}{|c|c|}
\hline 対象地域 & $\begin{array}{r}\text { 松山市, 東温市, 松前町 } \\
\text { 砈部町おざ惐 }\end{array}$ \\
\hline 調査時期 & 2007 年 11 月 1月 \\
\hline 対象者 & 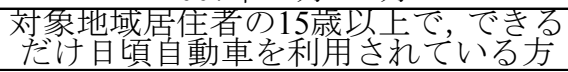 \\
\hline $\begin{array}{l}\text { 回収サン } \\
\text { プル数 }\end{array}$ & 555 人 \\
\hline 調查項目 & $\begin{array}{c}\text { 1週間の全ての移動，目的地・利用交 } \\
\text { 通手段など }\end{array}$ \\
\hline
\end{tabular}

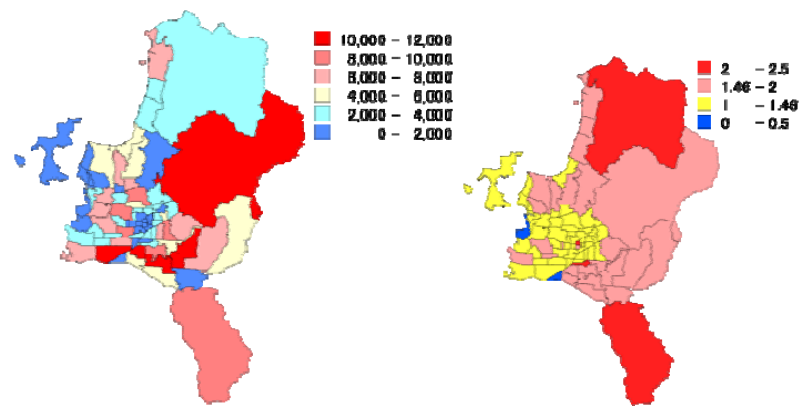

図-4 自動車保有台数

図-5 1世帯当たりの平均自動 車保有台数

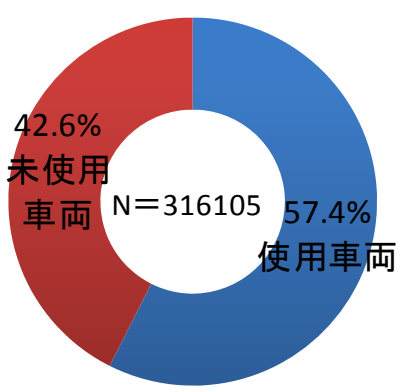

図-6 自動車利用状況

ため，そのことを考慮して考察を行う.

\section{3. 自動車保有 ・利用の現況}

図-4 にゾーン別自動車保有台数の集計結果を示す. 他のエリアと比べて都心部が少なくなっているが，これ は，都心部に都市機能が集積しているため，自動車利用 ニーズが相対的に低いためであると考えられる. 次に, 1 世帯当たりの平均自動車保有台数（図-5）を見る. 全 国平均 1.11(台/世帯) ${ }^{9)}$ と比較すると, 松山市の平均は 1.46(台/世帯)となっており，自動車に依存していること がわかる. 特に郊外に平均保有台数よりも保有台数が多 い世帯が多数存在している. 郊外は公共交通のサービス 水準が低いため，自動車依存度が極めて高いと言えよう。 また，自動車の利用状況（図-6）を見ると，分析対象自 動車の約 4 割が調査日に全く利用されていないなど，自 動車の稼働率は決して高くないことが判明した. 


\section{4. 平日1日におけるカーシェアリングシステムの 潜在需要}

\section{(1) 分析手法}

次節で述べる設定を用いて，自動車利用をカーシェア リングで代替した場合に，利用費用が節約できる場合は 自動車を削減可能であるものとして，潜在需要が高いエ リアを推定する.ここで，1 章で述べたように，本稿に おける潜在需要が高いエリアとは，削減可能な自動車が 多いエリアである。しかし，節約コストが拮抗している 場合，カーシェアリングへ転換する可能性が高いとは言 い難い。そこで，転換しやすさの指標として，節約費用 を算出した，なお，本研究では，松實らと同様に，各世 帯の自動車のうち，1 日の総移動距離が最も長い自動車 をファーストカー, それ以外の自動車をセカンドカーと 定義した.

\section{（2）利用費用の設定}

自動車の利用費用については，駐車場料金を $P$ (円) 月）, PT 調査から得られる各自動車の 1 日の総移動距 離を $L(\mathrm{~km})$, 総移動時間を $t$ （分）, 燃費を $10 \mathrm{~km} /$, ガソリン価格を 125 円/1として次式により算出した.

自動車の 1 日あたりの利用費用

$=$ （月当たりの自動車保有コスト十駐車場代） $\div 30$ 日十自動車利用コスト

$$
=(19349+P) \div 30+(L \div 10 \times 125)
$$

なお，自動車保有コストについては自動車価格，自動 車保険，自動車税を考慮したものであり，Pについては， C ゾーン単位で松山市の月極駐車場料金を調べた值を用 いた. (図-7)ただし，今回用いたデータの $63 \%$ が持ち家 の世帯であり，その世帯については月極駐車場料金を無 料にした.

カーシェアリングの利用費用は，松山市で実際にカー シェアリングシステムを事業運営している「三福カーシ エアリング」 ${ }^{10)}$ の料金体系を参考に次式を用いて算出 した.

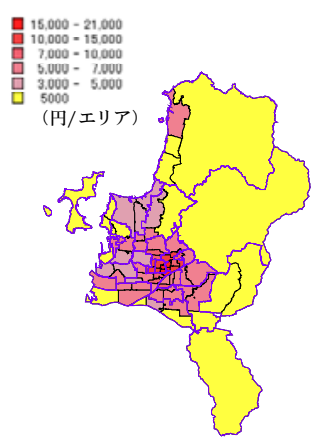

図-7 駐車場料金設定

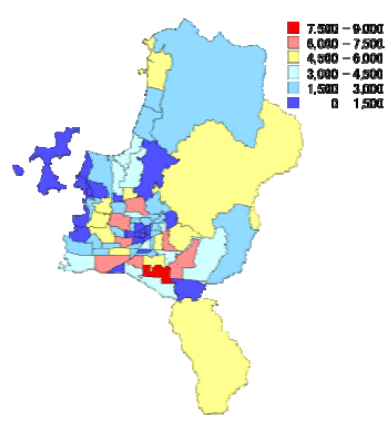

図-8ＣS 導入による自動 車削減可能台数
カーシェアリング利用による 1 日あたりの費用

$=($ 入会金十月会費 $) \div 30$ 日十時間料金十距離料金

$=2625 \div 30+(t \div 15 \times 250)+L \times 15$

\section{(3) 分析結果}

図-8 にカーシェアリング導入による自動車削減可能 台数を示す，都心部は削減可能台数が少なく，都市周地 区や郊外地区に削減可能台数が多いことがわかる。これ は，図-4 とほぼ同じ分布をしていることから，自動車 保有台数の影響によるものと考えられる，そこで，エリ ア内の自動車の台数を，同エリア内の自動車削減可能台 数で除したものである, カーシェアリング導入による自 動車削減可能割合（図-9）を見ると，都市周辺地区の削 減可能割合が約 7 割以上あり，自動車削減可能台数，削 減可能割合から，カーシェアリングの潜在需要は都市周 辺地区が高いといえよう. カーシェアリング導入による 総節約費用（図-10）を見ると，都市周辺地区の節約金 額が高いことがわかる，なお，松山市全体では，約 22 万台，約 7 割の自動車が削減可能であり，金額に換算す ると 1 台当たり平均約 500 円，年間約 18 万円節約可能 であることがわかった。これは，あくまで平日 1 日のデ 一夕に基づくいわば上限值を示すものであるが，カーシ エアリングシステムの潜在需要は十分に高いものと思わ れる。

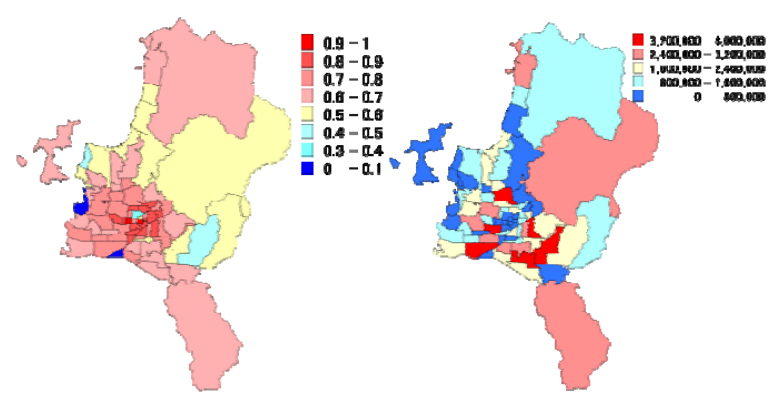

図-9ＣS 導入による自 動車削減可能割合
図-10ＣS 導入による総節約 費用

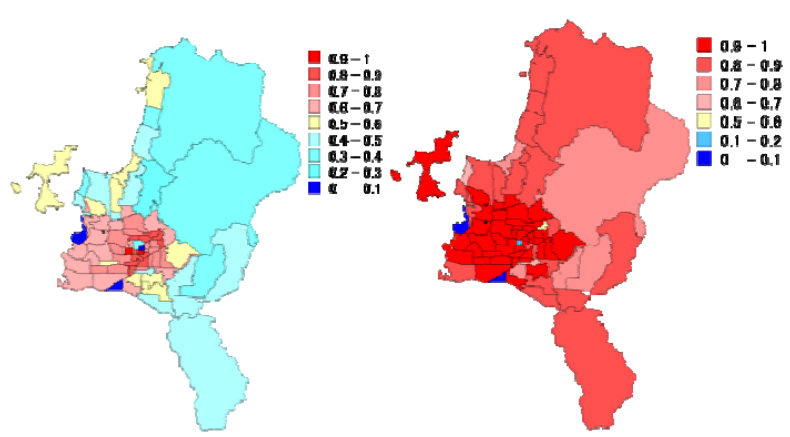

図-11 CS 導入によりファース トカーが削減可能な世帯 の割合
図-12 CS 導入によるセカン ドカーの削減可能割合 
次に, カーシェアリング導入によりファーストカーが 削減可能な世帯の割合と，セカンドカーの削減可能割合 をそれぞれ算出した（図-11，図-12）。両者を比較する と，どのエリアにおいてもセカンドカーの削減可能割合 が高くなっている. これは, 定義上, セカンドカーの方 が移動距離が短い自動車ということにもよるが，ファー ストカーの移動距離（図-13）, セカンドカーの移動距 離（図-14）を比較すると, セカンドカーは移動距離が $5 \mathrm{~km}$ 未満の車両が未使用を含めて約 8 割と多く, 非常に 利用が少ないといえよう。特に都市周辺地区では 9 割近 くの世帯で削減可能であることから，カーシェアリング の潜在需要は都市周辺地区で高く, またセカンドカーを ターゲットとしたシステムが有効であるものと考えられ る.

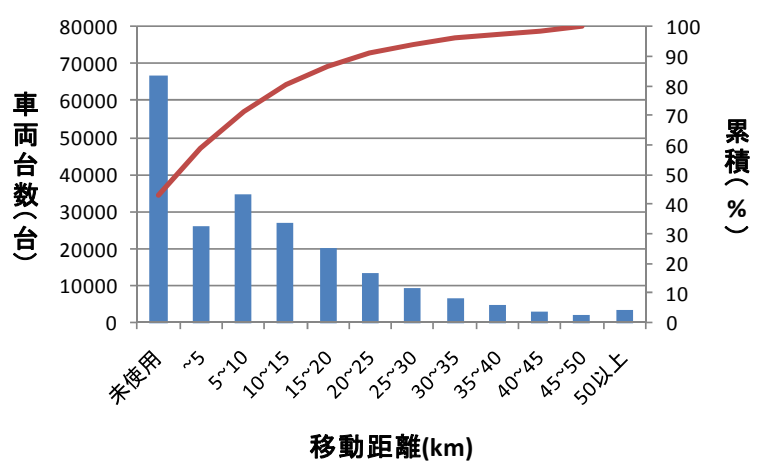

図-13 ファーストカーの移動距離

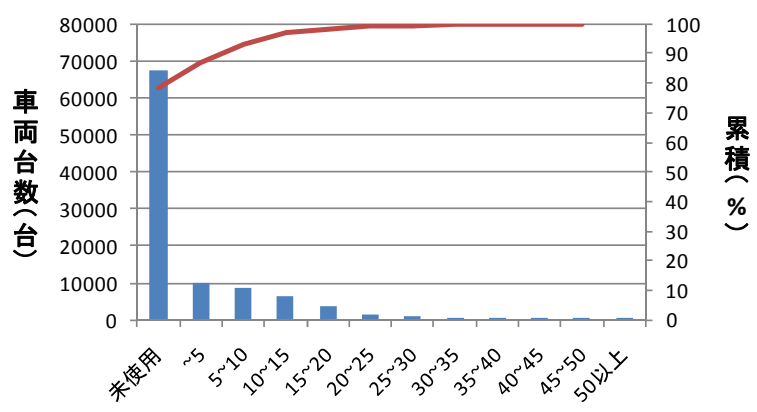

移動距離 $(\mathrm{km})$

図-14 セカンドカーの移動距離

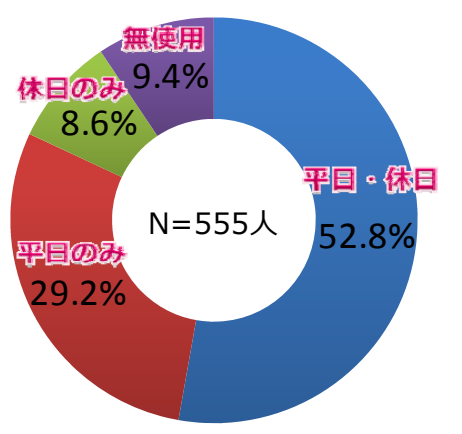

図-15 平日・休日における自動車利用状況

\section{1週間における自動車の利用状況}

図-15 に平日・休日における自動車利用状況を示す. $\mathrm{PP}$ 調查はできるだけ日頃自動車を使われている方が対 象者にも関わらず, 1 週間全く自動車を使用していない 人が約 1 割おり， 1 週間単位で自動車利用状況を見ても, あまり利用がされていない可能性があると推察できる. また，図-16 の平日・休日における自動車使用日数の割 合を見ると，全く自動車を利用していない人から，平日 5 日間全て利用している人まで割合はほぼ均一となって おり，自動車の利用頻度は個人によってばらつきがあり， PT 調查での潜在需要分析結果が過大評価である可能性 がある.

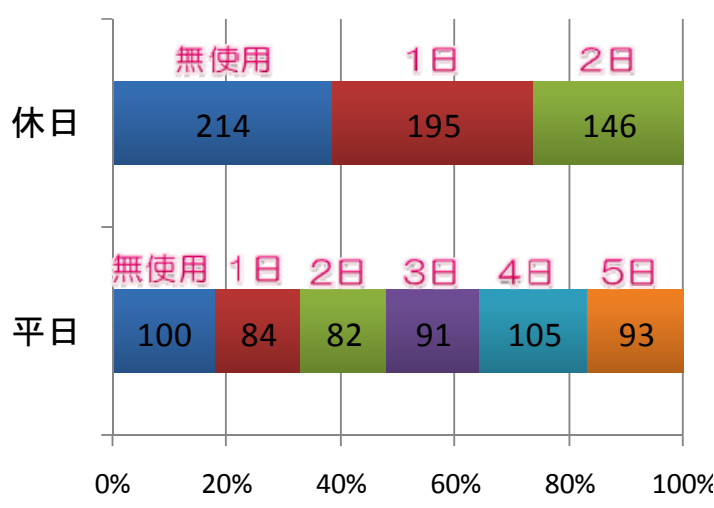

図-16 平日・休日における自動車使用日数の割合

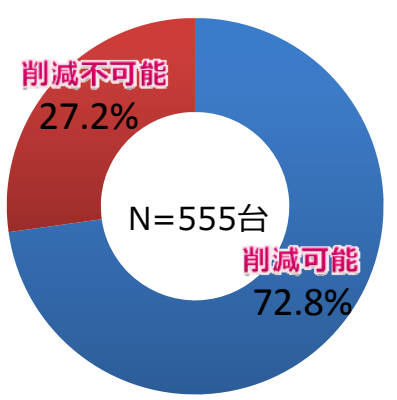

図-17CS 導入による自動車削減可能割合

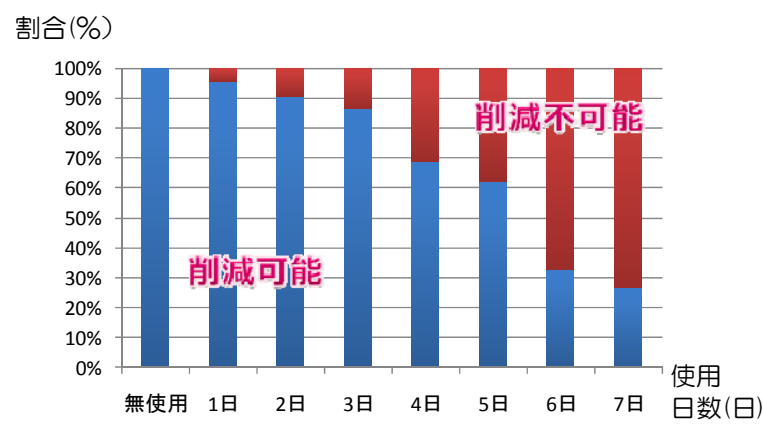

図-18 自動車利用日数別の削減可能割合 


\section{1 週間におけるカーシェアリングシステムの潜 在需要}

\section{(1) 分析手法}

PT 調査で行った分析と同様に式(1)，(2)より，自動車 利用をカーシェアリングで代替した場合に，利用費用が 節約できる場合は自動車を削減可能であるものとして, その車両台数と節約費用を算出した。ただし，持ち家か 否かのデータがないため，駐車場料金については全ての 自動車に図-7の料金を負荷している.

\section{(2) 分析結果}

図-17 にカーシェアリング導入による自動車削減可能 割合を示す．約 7 割の自動車が削減可能である．利用日 数別の削減割合（図-18）を見てみると，一週間におけ る利用日数が増えるほど削減割合が減少していることが わかる，つまり，自動車をよく利用している人ほどカー シェアリングに転換する可能性は低い。一週間全て自動 車を利用した場合，約 7 割の自動車が削減不可能である ことがわかった．また，削減可能な自動車の平均節約可 能額を計算すると，一週間で 1 台当たり 3419 円節約可 能で，年間に換算すると約 18 万円の節約効果が得られ る結果となった. 今回のデータは自動車を普段よく使っ ている人が対象であるため，実際はより節約可能額が増 えると考えられる.これらの結果から，松山都市圏にお けるカーシェアリングの潜在需要は高いと推察できる.

\section{7. おわりに}

本研究は，松山 PT 調査データを用いて世帯の自動車 保有・利用状況を把握し, 次いでカーシェアリングへの 転換による利用者の経済的メリットに着目して分析を行 い，カーシェアリングへの転換可能性を検討した. 結果, 松山市の約 7 割の自動車が削減可能で, 特に都市周辺地 区のセカンドカーが削減可能であることがわかった。さ らに PP 調査を用いた一週間単位での分析を行った結果, 約 7 割の車両が削減可能であることがわかった. これら の結果から，松山都市圈におけるカーシェアリングの潜 在需要は高いといえよう。

しかし，本分析では自動車利用すべてを潜在需要の候 補としていることから，潜在需要の上限值を示している ことに注意しなければならない，実際には，自動車を手 放すには至らないが，カーシェアリングに加入する層,
自動車を手放したが，カーシェアリングに加入せず別の 交通手段で代替する層，自動車を保有しておらず，別の 交通手段で行動していたが，カーシェアリングに加入す る層など様々な層が考えられる.さらにはカーシェアリ ングシステムのサービスレベル（自宅からデポまでの距 離や，料金体系など）を考慮した分析が必要である.加 えて, 自動車保有心理や, 利用意識についても分析を行 う必要がある。

謝辞：本研究を実施するにあたっては，文部科学省科学 研究費補助金（基盤研究(A), 課題番号 : 21246080, 研究 代表者 : 羽藤英二) の助成を受けた. ここに記して感謝 の意を表します。

\section{参考文献}

1)太田裕之, 藤井聡, 西村良博, 小塚みすず：カーシ ェアリング加入促進手法についての実証的基礎研究, 土木学会論文集, Vol.64, No.4, pp.567-579, 2008.

2) 平石浩之, 中村文彦, 大蔵泉：カーシェアリング社 会実験の現状と導入に向けた計画手法の課題, 土木 学会論文集, No.786/IV-67, pp.3-10, 2005.

3) 竹内新一, 谷口栄一: 業務交通を対象としたカーシ エアリング実証実験，土木学会論文集，No.786/IV-67, pp.21-29, 2005.

4) 平石浩之, 中村文彦, 大蔵泉：通勤利用における自 動車共同利用の需要推定に関する考察, 土木計画学 研究・論文集, Vol.19, No.3, pp.473-480, 2002.

5) 交通エコロジー・モビリティー財団 HP： http://www.ecomo.or.jp/index.html

6) 松實崇博, 倉内慎也, 山本俊行, 森川高行 : 自動車 保有・利用費用に着目した自動車共同利用システム に対する潜在需要の分析, 土木計画学研究発表会・ 講演集，Vol.36，2007.

7) 樋口誠, 青島縮次郎, 宿良：世帯における複数保有 車両の使い分けに関する平日・休日比較分析, 土木 学会年次学術講演会講演概要集第 4 部, Vol.49, pp.824-825, 1994.

8) Ye, X., Konduri, K., Pendyala, R. M, Sana, B. and Waddell, P.: A methodology to match distributions of both household and person attributes in the generation of synthetic populations, Submitted for Presentation Only to the $88^{\text {th }}$ Annual Meeting of the Transportation Research Board, 2009.

9）財団法人 自動車検查登録情報協会 HP : http://www. airia.or.jp/

10) 三福カーシェアリング HP : http://www.3puku.co.jp/ car/

(2011.2. 25 受付) 


\section{INVESTIGATION OF THE POTENTIAL DEMAND FOR CAR SHARING \\ IN MATSUYAMA METROPOLITAN AREA FOCUSING ON THE COST OF VEHICLE OWNERSHIP AND USE}

\section{Tatsunori ISHIMURA, Shinya KURAUCHI and Tatsuhiko HAGIO}

This study aimed at getting the basic information that was necessary for the car sharing spread in Matsuyama that was a local city and analyzed latent demand.We compared a cost by the car sharing with a cost by car ownership, the use. If a cost was reduced by car sharing, We defined it when We could reduce the car and We could reduce it and carried out the estimate of an area with much number. As a result of analysis per 1st when We used PT investigation, We were able to reduce about $70 \%$ cars of Matsuyama. Reduction possibility is in particular high the second car of the city outskirts district. It was recognized that We could reduce about $70 \%$ cars by the analysis by the hit for one week when We used PP investigation. 